DOI: $10.31866 / 2410-1915.21 .2020 .208260$

UDC 792:7.038.3](477)"199/20"

\title{
VISUAL PLASTIC EXPRESSIVENESS IN THE CONTEXT OF THE UKRAINIAN THEATRE ART DEVELOPMENT (the 1990s - early 2000s)
}

\author{
Ruslan Nykonenko
}

Lecturer, ORCID: 0000-0002-8379-7857, ruslanikonenko@gmail.com, Kyiv Municipal Academy of Circus and Variety Arts, 88, Zhylianska St., Kyiv, 01032, Ukraine

\section{For citations:}

Nykonenko, R. (2020). Visual Plastic Expressiveness in the Context of the Ukrainian Theatre Art Development (the 1990s - early 2000s). Culture and Arts in the Modern World, 21, 231-240. https:// doi.org/10.31866/2410-1915.21.2020.208260.

The purpose of the article is to identify the characteristic features of the use of visual plastic expressiveness by the Ukrainian stage directors in the 1990s and the early 2000s based on art review of theatrical productions of avant-garde, drama theatres and studio theatres. Research methodology. The typological method is applied to identify influence factors of the actualization of visual plastic expressiveness; due to the semiotic method the means of plastic expressiveness are considered according to the theory of signs and sign systems as artistic and aesthetic symbols that carry generalized sense information; art review method was used to identify the main features of using plastic expressive means by the Ukrainian theatre directors. Research Novelty. For the first time in domestic art studies, the problems of visual plastic expressiveness in the works of the Ukrainian directors of avant-garde, drama theatres and studio theatres in the 1990s and the early 2000s were studied; art review of theatrical stage production of V. Bilchenko, V. Troitskyi and A. Zholdak identified the individual features of the use of plastic expressive means by the Ukrainian theatre directors with the aim of revealing sense and meaning content of stage works. Conclusions. The study showed that in the Ukrainian theatre art of the late $20^{\text {th }}$ - early $21^{\text {st }}$ centuries directorial search in the field of visual plastic expressiveness was manifested primarily in the context of the active integration of various plastic elements as an addition to the verbal structure of the stage production and/or its replacement at certain moments of the stage action, in accordance with the author's vision, in order to enhance the sense and meaning loading of the work. The correlation of expression and image in the modern Ukrainian theatre art generates innovative approaches to the understanding and mastering of plastic art.

Keywords: Ukrainian theatre art; plastic art; visual plastic expressiveness; plastic directing; performativity; stage productions. 


\section{Introduction}

The 1990s - early 2000s in the history of the Ukrainian theatre art is a period of global synthesis due to the extraordinary intensification of the convergence processes of various audio and visual arts elements.

In the 1990s domestic theatre directors integrated a variety of genre models and means of plastic expression into their artistic construction created by the laws of dramatic art.

The research of peculiarities of the Ukrainian theatre art development of the specified period in the context of the directorial search in the field of visual plastic expressiveness, in our opinion, is highly relevant and necessary, since it gives understanding and comprehension of the modern trends of plastic directing developments in the domestic stage space at the end of the $20^{\text {th }}$ - early $21^{\text {st }}$ centuries, and also makes possible to track the emergence of innovative elements and analyse the impact of certain types of visual arts on the theatre arts.

The research novelty lies in the fact, that for the first time in the domestic art studies the problems of visual plastic expressiveness in the works of Ukrainian directors of avant-garde, drama theatres and studio theatres in the 1990s and the early 2000s were studied; peculiarities of convergence of audio and visual arts elements in the context of domestic theatre space of the specified period are considered; art review of theatrical stage productions of V. Bilchenko, V. Troitskyi and A. Zholdak identified the individual features of the use of plastic expressive means by the Ukrainian theatre directors with the aim of revealing the sense and meaning content of stage works.

The research analysis demonstrates the presence in the domestic scientific dimension of many works devoted to the development of the Ukrainian theatre art in the 1990s-2000s. In particular, these are the works of S. Vasyliev (2018) "Escape for freedom: on some aspects of being Ukrainian alternative theatre in the 1980s-2000s" in which the researcher examines the efforts of young Ukrainian directors to construct "their own opportunistic artistic strategies" in the context of public or alternative theatre, and of M. Hrynyshyna "Urban and world: drama by A. Chekhov at the Ukrainian field in the inter contextual ties with the world theatre space" devoted to the experience of the Ukrainian theatre directors in performing stage interpretations of A. Chekhov's dramaturgy. Analysing the state of the theatre in Ukraine, the group of authors make an attempt to identify the main indicators of success and leaders, trends and vectors of the theatre development (Vasyliev et al., 2018).

However, individual directorial searches in the field of visual plastic expressiveness of the Ukrainian theatre director V. Bilchenko, V. Troitskyi and $\mathrm{A}$. Zholdak in the context of leading trends of stage space of the late $20^{\text {th }}-$ early $21^{\text {st }}$ centuries and in the perspective of the national theatrical art development have not yet been the subject of special scientific research. 


\section{Purpose of the article}

The purpose of this article is to identify the characteristic features of the use of visual plastic expressiveness by the Ukrainian stage directors in the 1990s and the early 2000s based on art review of theatrical productions of avant-garde, drama theatres and studio theatres.

The purpose of the article requires the following issues to be solved: to identify influence factors of the actualization of visual plastic expressiveness in the domestic theatrical dimension of the late $20^{\text {th }}$ - early $21^{\text {st }}$ centuries:

- to consider the means of plastic expressiveness in accordance with the theory of signs and sign systems as artistic and aesthetic symbols that have generalized sense information;

- to identify the characteristic features of the use of visual plastic expressiveness by Ukrainian stage directors;

- to reveal the directorial methodology of V. Bilchenko, V. Troitskyi and A. Zholdak in the context of genre features of dramas, performances and theatrical projects.

The article provides an interdisciplinary approach to comprehensively review the above-indicated issues. The typological method, the semiotic method, art review method, the genre and typological method have been applied.

\section{Main research material}

Due to the desire to abandon the traditional models of theatrical directing in the global stage space in the late $20^{\text {th }}$ - early $21^{\text {st }}$ centuries a paradigm was formed and it corresponded to a single artistic model - the removal of any restrictions on creative expression, starting from the idea to the ways of its implementation. As a result of open borders in the early 1990s the active integration of foreign creative experience into Ukrainian culture and art contributed to the formation and development of art forms innovative for the domestic social and cultural space - performances, art events, video art, happenings, etc., whose specific features (for example, the peculiarities of artistic language, new vistas for drama and prose, non-standard organization of spatial action, the use of interactive techniques, etc.) greatly expanded the possibilities of plastic performance, contributed to the invention of new directing techniques and methods. According to researchers, the peculiarities of the postmodern and new media eras conditioned the interconnection and mutual influence of various types of art and as a result "visual and plastic art turns to the principles of performativity with increasing frequency" (Trykolenko, 2016, p. 62).

The means of plastic expressiveness belong to non-verbal (visual) linguistic units of expressiveness of the genres of theatrical productions and are positioned as artistic and aesthetic symbols which, while replacing verbal units, carry certain generalized sense information about the symbols encoded in them. When naturally combined with verbal (audio) means of expression, the elements of plastic culture significantly emphasize and enforce the sense and meaning content of the statement, draw attention to those sense acts of 
artistic communication that convey the feelings of the author and the performer.

Researchers emphasize the importance of a harmonious balance between plastic expressiveness and other means of expressiveness of the actor, whose organicity is determined according to the conditions of the stage space. For example, G. Morozova (1999) states that in drama theatre body expressiveness is an integral part of the complex of acting skills: the term "plastic expressiveness of the dramatic actor" is used to evaluate the actor's plastic in the role and therefore, is identical to the term "body expressiveness" (p. 185). Unlike choreographic or pantomimic production, where the concept of plastic expressiveness corresponds to the canons formed in these types of art, in the theatrical art it involves the presence of bright genre and style characteristics of the character's external behaviour and the correspondence of the forms of action to its sense and meaning loading.

The specificity of the use of visual plastic expressiveness depends on the director's ability and need to realise the stage action or its elements in a figurative, artistically meaningful plastic form, replace and/or strengthen the audio means of expression (as carriers of meaning) with visual ones, make them dominant and defining in the style of theatrical production.

The activity of domestic directors of newly created alternative theatres and studio theatres in the 1990s was characterised by intense actualization of creative searchers in the field of visual plastic expressiveness.

The stylistic unity, multidimensionality and metaphor nature of the plastic elements contribute to the revealing of character's personality and the essence of the events of theatrical productions of one of the leading Kyiv directors of the first half of the 1990s V. Bilchenko "Archeology" (1989) and "And said B" (1991) based on the plays of O. Shypenko "The crow", "La Funf in der Luft" performed on the stage of the Kyiv Youth Theatre.

At the beginning of 1993, the director trying to find the new form of the theatre as "the embodiment of materialized stylistics and philosophy" (Briukhovetska, 1998, p. 52) together with a group of professional actors from the Youth Theatre, creates the author's Experimental Theatre Studio in the premises provided by Kyiv-Mohyla Academy. A unique group of actors led by director-experimenter whose creative search was characterised by the desire to realise the dream of Les Kurbas about a philosopher-acrobat, "intellectual harlequin", later, in addition to work on dramatic production ("Eastern March" on the material of the "Ukrainian diaries" of Danish actress K. Kolstrup and improvisational etudes of troupe of actors, 1995; "The Falcon" by D. Bortnianskyi, 1996) and patronage of student's theatrical creativity, he was involved into the production of street plays ("Description of the Monster No 1", 1993; "Wild Theatre" (together with A. Petrov), 1994), which were distinguished by the topicality of the themes and spectacularity thanks to the various means of plastic expressiveness and extreme features.

According to his own vision of the development of the alternative theatre in Ukraine, V. Bilchenko staged the performance "Shot in Autumn Garden" based on the play "The Cherry Orchard" by A. Chekhov, which is regarded by 
the Ukrainian theatrical experts as the best performance of the metropolitan theatre space of the $90 \mathrm{~s}$ of the $20^{\text {th }}$ century. (Vasyliev et al., 2018, p. 9). In the performance the director used a variety of plastic discursive models skillfully integrating them into the general action. M. Hrynyshyna (2008) emphasizes that "emblematic review of techniques from depositories of the word, theatre, cinema, painting - a characteristic feature of the style of the performance - by the powerful collective effort from the too familiar Chekhov's reality extracted new intonations, other trajectories of its space, renewed sensory perception of the action and showed its immediacy" (p. 355).

Organic plastic solution of the staging, which emphasized the director's focus on the context of the plot, the monologue nature of the characters' existence, "the depth of the form (...) of self-realisation and "existential" meaning" (Bilchenko, 1993, p. 15) was intensified by the synthesis with S. Mykosovskyi's set design which is cinematic by structure, L. Podervianskyi' costumes, and vocal, words (actors: K. Kolstrup - Ranevska, T. Shuran - Varia, V. Aleksiienko Lopakhin, S. Matviiko - Trofimov, S. Fesenko - Yasha, V. Avdieienko - Duniasha, Ya. Chornenkyi - Haiev) and other systematic elements of the theatrical space, created a state of syncretism of languages of the play, and according to M. Hrynyshyna (2008), significantly expanded the boundaries of the "theatrical Chekhov", delegating it to other art spaces (p. 353-354).

In 1994, as a contrast to the National Theatre, V. Troitskyi founded a Centre of Contemporary art "Dakh" - theatrical space in Kyiv, in the structure of which, apart from the theatre studio (director of the psychological Ukrainian theatre, realist-master V. Ohloblin, V. Bilchenko, playwrite Klim), an acting and directing school was opened later, music side-projects were created ("ethnic chaos" band DakhaBrakha, freak-cabaret "Dakh Daughters"), educational lectures, workshops (B. Yukhanov, I. Lysov), art meetings and etc., are actively held. According to the domestic researchers, the creative style of the theatre's art director V. Troitskyi is inspired by modern practices and archaic rituals (Vasyliev, 2018, p. 18), presenting artistic projects and performances characterized by multilayered form and content, the skill to speak about complex philosophical issues by means of plastic expressiveness, enhanced by musical accompaniment, naturally combining it with emotional and lyrical texts.

For example, the director has successfully created an atmosphere of national ritual in the trilogy "In search of the Lost Time...Life" (performances "Life", "Faith”, “Earth”, Centre of Contemporary art "Dakh”, "Pectoral” 2002) thanks to the cooperation with folk group "Bozhychi". Despite the dominance of audio means of expression in the production, the national culture and special type of thinking are hidden behind the corporal signs used by V. Troitskyi and it ensures the existence and realisation of certain ways of plastic expression of sense.

In philosophical and aesthetic thought plastic in combination with rhythmic basis is associated with magical rituals, ancient mysteries and cults where they had special symbolic nature and are equated to the manifestation of the divine origin of a man.

In V. Troitskyi's stage direction, which is characterised by the dominance of the means of visual plastic expressiveness as complex of artistic and aesthetic 
symbols full of deep metaphoric meaning, the specific feature is the combination of sound and movement in a unique sound rhythmic coding.

For example, the project "Mystical Ukraine" (staging of "Prologue to Macbeth", "Richard III" and "King Lear") is of interest in the context of the combination of the director's visual means of expression with the musical accompaniment, a kind of musical-plastic act in which national mythology is synthesized with European theatrical tendencies - national ritual is combined with classics of world drama. In order to create a unique mythical atmosphere, the above mentioned "ethnic chaos" band DakhaBrakha (the stylization of the Ukrainian folk melos is used in staging - a combination of traditional national songs with urban rhythms of the beginning of the $21^{\text {st }}$ century, British texts and Buddhist gong positioned as a structural element of the theatrical mystical action) was founded by V. Troitskyi. The director's staging of the most famous works of Shakespeare done in the form of a theatre-ritual surprises us by the lack of plot, verbal means of expression and narrative - V. Troitskyi completely abandoned the way of descriptive presentation of the plot by demonstrating the meaningful events of the works, and created a unique atmospheric sketch in the visual and audio environment, the sense and meaning content of which the viewer must first of all feel, not understand. According to the director's vision, actors creating a mystical atmosphere perform their own plastic drawing and are perceived rather as symbolic figures with motionless faces-masks (Myhashko, 2016).

The use of the plastic means of expression by the director's as principal one in the stage production in the artistic space of the Ukrainian theatre at the end of the $20^{\text {th }}$ - early $21^{\text {st }}$ centuries is positioned as a powerful means of influence on the consciousness of the viewer. In this context, V. Troitskyi's appeal to visual plastic means of expression is positioned as an attempt to introduce to the viewer the ancient sources of mankind, since the body preserves the information that has disappeared from the consciousness long time ago.

The peculiarity of the convergence of various audio and visual arts elements in the conditions of theatrical space distinguishes A. Zholdak's performances, in which the director tends to emphasize the typical features of postmodernism focusing the viewer's attention to the actor's body.

For example, in the performances of "Carmen" based on the P. Merimee's short story (single-show project, premiered on the $25^{\text {th }}$ of June, 1997, Lesia Ukrainka National Academic Theatre of Russian Drama in Kyiv) and "Marriage" based on the M. Hohol's play (Cherkasy Regional Theatre of Music and Drama, 2001) A. Zholdak having moved away from the elements of the verbal level, made postmodern visual plastic expressiveness the dominant.

In the production "Goldoni. Venice" (T. Shevchenko Academic Ukrainian Drama Theatre "Berezil" in Kharkiv, 2004) A. Zholdak moves away from the verbal component and author's literary primary source as much as possible, presenting the performance based not on C. Goldoni's “The Servant of Two Masters", but, according to domestic art experts, "on the potentially meaningful and formative plot "Venice - masks", dynamizing to a great extent the visual 
aspects of the stage action and "deploying plastic exercises both on stage and all levels of the auditorium” (Miziak, 2012, p. 186).

Ukrainian theatre art of the 1990s - early 2000s is characterised by conditional and realistic tendencies of using plastic means of expression which coexist and come into collision depending on the individual director's vision. Actor's gestures, facial expression, body movements and plastic are modified from extremely metaphoric features to the ones that are close to natural communication.

Creative experiments of the Ukrainian theatre directors V. Bilchenko, V. Troitskyi and A. Zholdak contributed to the improvement of non-verbal technique in general and plastic expressiveness in particular, destruction of irrelevant templates and clichés, development of innovative techniques and methods of plastic solution according to the needs of the Ukrainian theatre art.

\section{Conclusions}

The study showed that in the Ukrainian theatre art of the late $20^{\text {th }}-$ early $21^{\text {st }}$ centuries directorial search in the field of visual plastic expressiveness was manifested primarily in the context of the active integration of various plastic elements as an addition to the verbal structure of the stage production and/or its replacement at certain moments of the stage action, in accordance with the author's vision, in order to enhance the sense and meaning loading of the work. The correlation of expression and image in the modern Ukrainian theatre art generates innovative approaches to the understanding and mastering of plastic art.

As a result of art analysis of theatrical productions of V. Bilchenko, V. Troitskyi and A. Zholdak, it has been found that in the directors' work the plastic should be positioned as the dominant element that facilitates the synthesis of all systemic elements of theatrical space.

Further research prospects are a complex review of plastic stage directing in the Ukrainian theatre art of the late $20^{\text {th }}$ - early $21^{\text {st }}$ centuries.

\section{References}

Bilchenko, V. (1993). Mene tsikavyt podiia z liudynoiu [I am interested in an event with a person]. Ukrainskyi teatr, 4,15 [in Ukrainian].

Briukhovetska, L. (1998). Stykhiia hry [Element of acting]. Kino-Teatr, 6, 52-53 [in Ukrainian].

Hrynyshyna, M. O. (2008). Mistovi y svitovi: dramaturhiia A. P. Chekhova na ukrainskomu konu $v$ interkontekstualnykh zviazkakh iz svitovym stsenichnym prostorom [Urban and world: drama by A. Chekhov at the Ukrainian field in the inter contextual ties with the world theatre space]. Intertekhnolohiia [in Ukrainian].

Miziak, V.D. (2012). Andrii Zholdak: berezilskyi dosvid teatralnoho postmodernu [Andrii Zholdak: Berezil's experience of the theatrical postmodern]. Kultura Ukrainy, 39, 181-189 [in Ukrainian].

Morozova, G. V. (1999). Plasticheskaia kultura aktera. Tolkovyi slovar terminov [The plastic culture of an actor. Explanatory dictionary of terms]. GITIS [in Russian]. 
Myhashko, O. (2016). Vlad Troitskyi. Teatr yak manifest. Teatr yak rytual [Vlad Troitskyi. Theatre as a manifest. Theatre as a ritual]. Teatre. http://teatre.com.ua/portrait/ lad-rojtskyj-eatr-jakmanifest-eatr-jakrytual/ [in Ukrainian].

Trykolenko, S. T. (2016). Ukrainska stsenohrafiia kintsia XX - pochatku XXI st.: osnovni tendentsii rozvytku ta avtorski pozytsii [Ukrainian scenography of the late $20^{\text {th }}$ early 21 $1^{\text {st }}$ centuries: the main tendencies of development and author's viewpoint]. (PhD Dissertation). Rylsky Institute of Art Studies, Folklore and Ethnology, Kyiv [in Ukrainian].

Vasyliev, S. (2018). Vtecha za svobodoiu. Pro deiaki aspekty pobutuvannia ukrainskoho alternatyvnoho teatru 1980-2000-kh [Escape for Freedom: On Some Aspects of Being a Ukrainian Alternative Theatre in the 1980s-2000s]. MIST: Mystetstvo, istoriia, suchasnist, teoriia, 14, 17-44 [in Ukrainian].

Vasyliev, S., Chuzhynova, I., Sokolenko, N., Salata, O., Tukalevska., O, \& Zhyla, V.(2018). Ukrainskyi teatr: shliakh do sebe. Zdobutky. Vyklyky. Problemy [Ukrainian theatre: the Way to Thyself. Achievements. Challenges. Problems]. Sofiia [in Ukrainian].

\section{ВІЗУАЛЬНА ПЛАСТИЧНА ВИРАЗНІСТЬ У КОНТЕКСТІ РОЗВИТКУ УКРАЇНСЬКОГО ТЕАТРАЛЬНОГО МИСТЕЦТВА (1990-ті - ПОЧАТОК 2000-х рp.)}

\section{Никоненко Руслан Миколайович}

Викладач, ORCID:0000-0002-8379-7857, ruslanikonenko@gmail.com, Київська муніципальна академія естрадного та циикового мистецтв, Київ, Україна

Мета статті - виявити специфіку використання візуальної пластичної виразності українськими режисерами в 1990-ті - на початку 2000-х рр. на основі мистецтвознавчого аналізу театральних постановок авангардних, драматичних театрів та театрів-студій. Методологія дослідження. Застосовано типологічний метод, що посприяв виявленню факторів впливу на актуалізацію візуальної пластичної виразності; семіотичний метод, завдяки якому засоби пластичної виразності розглянуто відповідно до теорії знаку та знакових систем як художньо-естетичні символи, що несуть узагальнену сенсову інформацію; метод мистецтвознавчого аналізу - для виявлення специфіки використання засобів пластичної виразності українськими режисерами та ін. Наукова новизна. Вперше у вітчизняному мистецтвознавстві досліджено проблематику візуальної пластичної виразності у творчості українських режисерів авангардних, драматичних театрів та театрів-студій у 1990-ті - на початку 2000-х рр.; на основі мистецтвознавчого аналізу театральних постановок В. Більченка, В. Троїцького та А. Жолдака виявлено специфіку та індивідуальні особливості використання засобів пластичної виразності українськими режисерами з метою розкриття сенсовозмістового наповнення сценічних творів. Висновки. Доведено, що в українському театральному мистецтві кінця XX - початку XXI ст. режисерські пошуки у сфері 
візуальної пластичної виразності проявилися передусім у контексті активного інтегрування різноманітних пластичних елементів як доповнення вербальної структури постановки та/або її заміни у певні моменти сценічної дії, відповідно до авторського бачення постановника, 3 метою посилення сенсово-змістового навантаження твору. Співвідношення вираження та зображення в сучасному українському театральному мистецтві породжує інноваційні підходи до осмислення та освоєння пластичного мистецтва.

Ключові слова: українське театральне мистецтво; пластичне мистецтво; візуальна пластична виразність; пластична режисура; перформативність.

\title{
ВИЗУАЛЬНАЯ ПЛАСТИЧЕСКАЯ ВЫРАЗИТЕЛЬНОСТЬ В КОНТЕКСТЕ РАЗВИТИЯ УКРАИНСКОГО ТЕАТРАЛЬНОГО ИСКУССТВА (1990-е - НАЧАЛО 2000-х гт.)
}

\author{
Никоненко Руслан Николаевич
}

\author{
Преподаватель, \\ ORCID: 0000-0002-8379-7857,ruslanikonenko@gmail.com, \\ Киевская муниципальная академия эстрадного и циикового искусств, \\ Киев, Украина
}

Цель статьи - выявить специфику использования визуальной пластической выразительности украинскими режиссерами в 1990-е - начале 2000-х гг. на основе искусствоведческого анализа театральных постановок авангардных, драматических театров и театров-студий. Методология исследования. Применен типологический метод, который помог выявлению факторов влияния на актуализацию визуальной пластической выразительности; семиотический метод, благодаря которому средства пластической выразительности рассмотрены согласно теории знака и знаковых систем как художественно-эстетические символы, несущие обобщенную смысловую информацию; метод искусствоведческого анализа - для выявления специфики использования средств пластической выразительности украинскими режиссерами и др. Научная новизна. Впервые в отечественном искусствоведении исследована проблематика визуальной пластической выразительности в творчестве украинских режиссеров авангардных, драматических театров и театров-студий в 1990-е - начале 2000-х гг.; рассмотрены особенности процессов конвергенции элементов визуальных и аудиальных видов искусств в условиях отечественного театрального пространства определенного периода; на основе искусствоведческого анализа театральных постановок В. Бильченко, В. Троицкого и А. Жолдака выявлена специфика и индивидуальные особенности использования средств пластической выразительности украинскими режиссерами с целью раскрытия смысловосодержательного наполнения сценических произведений. Выводы. Доказано, что в украинском театральном искусстве конца XX - начала XXI в. режиссерские поиски в сфере визуальной пластической выразительности проявились прежде всего в контексте активного интегрирования различных пластических элементов как дополнений вербальной структуры постановки и/или ее замены в определенные 
моменты сценического действия, в соответствии с авторским видением постановщика, с целью усиления смыслово-содержательной нагрузки произведения. Соотношение выражения и изображения в современном украинском театральном искусстве порождает инновационные подходы к осмыслению и освоению пластического искусства.

Ключевые слова: украинское театральное искусство; пластическое искусство; визуальная пластическая выразительность; пластическая режиссура; перформативность. 